\title{
The effects of greening the supplier and innovation on environmental performance and competitive advantage
}

\author{
Authors: \\ Unine van den Berg ${ }^{1}$ \\ Jean-Pierre Labuschagne ${ }^{1}$ \\ Hugo van den Berg ${ }^{2}$ \\ Affiliations: \\ ${ }^{1}$ Department of \\ Environmental Sciences, \\ University of South Africa, \\ South Africa \\ ${ }^{2}$ Department of Transport \\ and Supply Chain \\ Management, University of \\ Johannesburg, South Africa \\ Correspondence to: \\ Unine van den Berg \\ Email: \\ vdberu@unisa.ac.za \\ Postal address: \\ PO Box 392, UNISA, South \\ Africa, 0003 \\ Dates: \\ Received: 19 July 2013 \\ Accepted: 02 Sept. 2013 \\ Published: 31 Oct. 2013 \\ How to cite this article: \\ Van den Berg, U., \\ Labuschagne, J-P. \& Van \\ den Berg, H., 2013, 'The \\ effects of greening the \\ supplier and innovation on \\ environmental performance \\ and competitive advantage', \\ Journal of Transport and \\ Supply Chain Management \\ 7(1), Art. \#121, 7 pages. \\ http://dx.doi.org/10.4102/ \\ jtscm.v7i1.121
}

\section{Copyright:}

(c) 2013. The Authors.

Licensee: AOSIS

OpenJournals. This work

is licensed under the

Creative Commons

Attribution License.
Read online:

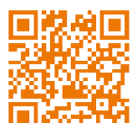

Scan this QR code with your smart phone or mobile device to read online.
Companies in South Africa should realise the important influence of greening their suppliers and of innovation to achieve environmental goals and competitive advantages. In order to prove this, a questionnaire survey was conducted with 75 companies from 11 industries in the City of Johannesburg Metropolitan Municipality region, South Africa. A confirmatory factor analysis was done, followed by bivariate correlations to determine the strength of association between the latent constructs. Correlations between greening the supplier, innovation, environmental performance and competitive advantages were done. The research found that a green innovative process had a significant effect on environmental performance. Green managerial innovation further had a significant correlation with competitive advantage. The primary result of the study indicated that all the constructs positively related to each other, meaning that greening suppliers, by means of green innovation, leads to an enhanced environmental performance and to competitive advantages.

\section{Introduction}

Companies and managers should regard environmental awareness skills as critical when recruiting employees. However, many companies perceive them to be the least important logistics and supply chain-related skills (Luke \& Heyns 2013). The Supply Chain Intelligence Report 2009 indicated that $40 \%$ of the surveyed companies were not implementing environmentally sustainable business strategies and were even unwilling to do so (SAPA 2009). However, the remaining $60 \%$ of companies that utilised Green Supply Chain Management (GSCM) strategies indicated that they had an advantage over their competitors and that they showed an increase in profitability and savings during purchasing and production (SAPA 2009). Companies may still perceive the change from a traditional supply chain to a more environmentally sustainable green supply chain as costly and an additional burden. However, with increased global environmental concerns, a demand for greener products and manufacturing processes, and pressure from governments, legislation, the public and customers, it is imperative that companies start greening their supply chain (Seman, Zakuan, Jusoh, Arif \& Saman 2012). Companies, their suppliers and stakeholders need to respond to the changing business environment and implement the latest trends and strategies in order to be competitive.

The aim of this study was to explore the relationship between greening the supplier, green innovation, environmental performance and competitive advantages in companies in the City of Johannesburg Metropolitan Municipality region. The objective of the study was to motivate companies to initiate the change from traditional supply chains to environmentally greenconscious supply chains.

\section{Literature review}

The difference between a Green Supply Chain (GSC) and a traditional supply chain is that the GSC uses best practices to minimise waste and emissions along the value chain (Kumar, Teichman \& Timpernagel 2012). Seuring (2013) defined green or sustainable supply chain management 'as the management of material, information and capital flow' between companies, whilst integrating environmental, social and economic goals. The aim of any supply chain is to reduce overall operating costs. A GSC, similar to a normal supply chain, consists mainly of suppliers, manufacturers, distributors, retailers and end-users (Li 2011; Zhu, Sarkis \& Lai 2013).

Green Supply Chain Management includes how companies source their raw materials or parts, reduce their packaging or waste, provide more environmentally-friendly products and measure the environmental performances of their suppliers. Internal and external barriers and drivers influence the adoption of such a supply chain (Walker, Di Sisto \& McBain 2008). Internal barriers are the costs that a company incurs for implementing GSCM and external barriers include legislation and poor supplier commitment. Internal drivers are organisational factors such as 
the commitment of top and middle management, employees and investors, whilst external drivers include legislation and regulations, customers, competitors, society and suppliers. A company is driven more by external drivers than internal drivers (Walker et al. 2008), but by adopting GSCM, business operations are able to overcome both internal and external barriers if continuous green innovation is implemented (Seman et al. 2012).

\section{Green innovation}

Constant innovation is needed to deal with the barriers and drivers in GSCM. Green innovation, according to Seman et al. (2012), is a new approach, idea, product, process or service that contributes to differentiation from competitors and reduces adverse environmental impacts. Innovations can include the efficient use of energy, materials, water, waste and transport. For a company to experience growth in the future, green innovation is needed to create new markets because market forecasts indicate that these fields will experience above average growth in the next 10 years, thus providing potential and opportunities (Walz \& Eichhammer 2012).

For companies to take advantage of green innovation they need to work closely with all stakeholders, especially their suppliers, to establish partnerships, appraisal systems and service level agreements. Knowledge needs to be shared and management must provide guidance. This requires attitude changes from all parties in terms of time, money and resource investments (Chiou et al. 2011). Green innovation may provide a platform for companies and their suppliers to collaborate.

The commitment of suppliers is important to this process, as the collaboration between suppliers and buyers or manufacturers can lead to green product innovation and the development of environmentally- acceptable material. Lee and Kim (2011) explored the role that suppliers play in assisting focal companies to conduct green innovation when developing products. The study revealed that greening the supplier positively influences green innovation and subsequent environmental and economic performance. For a company to initiate green innovation it needs to know where in the supply chain it can occur. Green innovation can be categorised into green product, green process, green management and green technology (Tseng et al. 2013). However, this study will only focus on the first three.

\section{Green product innovation}

Green innovation enhances the product value, which offsets the cost of environmental investments and improves the corporate image of a company. Many customers prefer to buy green products and will therefore support companies that offer these products (Parbhoo 2013). According to Zhu et al. (2013), in 1994, customers were willing to pay approximately $13 \%$ more for green products. Green product innovation pertains to the evaluation of a product's economical, technical and commercial feasibility. Green or eco-design means that a product can assist companies to improve their environmental performance as, in the process, the functionality of the products is reviewed and impacts on the environment can be mitigated (Tseng, Huang \& Chiu 2012). A study by Kurapatskie and Darnall (2013) revealed that companies who develop new green products and processes enjoy more benefits than companies who just modify existing products and processes.

\section{Green process innovation}

It is estimated that $75 \%$ of a company's carbon footprint is produced by its supply chain (Kroes 2011). The term cradle to grave, where both the process and the product end at the landfill site, will, in green process innovation, change to cradle to cradle, whereby the process re-uses the end-life product in the process. This innovative green process can ensure the recovery and re-use of the company's end-life products, leaving a better environment (Kumar et al. 2012). The lean manufacturing approach, where waste is eliminated in the process, should be followed to improve environmental performance (Caniëls, Gehrsitz \& Semeijn 2013). This can be achieved by reducing material in the production process, minimising energy and resource consumption, using more efficient machinery, recycling, reducing, reusing and implementing cleaner technologies. Early supplier involvement (ESI), in-house auditors to appraise the supplier's environmental performance and management support can lead to green process innovation (Tseng et al. 2012).

\section{Green management innovation}

Green management innovation is considered as one of the most important and sustainable ways to attain a competitive advantage (Tseng et al. 2013). The competitiveness of a company is dependent on the internal environmental leadership, culture and capability of the management.

External pressures do not lead to effective green innovations and the benefits associated with them. The leader in a company is the visionary who motivates employees to be part of the green innovation process (Chen, Chang \& Wu 2012). Managers need to distribute human resources and financial assets towards more environmentally sustainable strategies (Tseng et al. 2012). Management innovation consists of environmental awareness seminars and training on the reduction of natural and non-renewable energy resource consumption. Management should also ensure that suppliers are environmental management system (EMS) ISO 14000 certified and encouraged to reduce emissions and waste.

\section{Relationship between green innovation and environmental performance}

Green innovation pertaining to GSC has a positive effect on the natural environment. This is achieved by the reduction of waste and use of non-toxic, non-hazardous materials (Eltayeb, Zailani \& Ramayah 2011). However, there is a problem with the definition of green innovation as it is 
relative and does not have an absolute value. Research does not clearly separate green innovation from non-green innovation and therefore does not measure the degree of 'greenness'. All companies are then considered to be green innovators (Schiederig, Tietze \& Herstatt 2012). Only one study, by Chiou et al. (2011), was found where the correlation between green innovation and the direct or quantified impact on the environmental performance was specifically researched. The study found that green process innovation and green product innovation are positively associated with environmental performance. Through product design innovations, reuse and recycling of products, adherence to international standards, the sustainable sourcing of raw material, minimising emissions or waste and the evaluation of suppliers on environmental criteria, a company can generate benefits to the environment (Large \& Thomsen 2011). However, does it lead to a competitive advantage for a company?

\section{Relationship between green innovation and competitive advantage}

Due to the continuous changes in technology and the short life cycle of products, companies need to improve their green innovations in order to enhance their competitiveness (Tseng et al. 2013). The focal point of all companies is to save money and to reap maximum profits. By conducting product Life Cycle Assessments, pollution prevention or elimination strategies, product quality enhancements and reverse logistics, costs can be reduced (Walker et al. 2008). Such measures increase profitability and lead to a competitive advantage, but despite external drivers, few companies are dramatically changing their practices to be more environmentally sustainable (Kumar et al. 2012). The impact of green innovations directly affects the internal performance of a company and is positively associated with a company's competitive advantage. Innovation is therefore needed to stay competitive (Chen, Lai \& Wen 2006; Eltayeb et al. 2011).

\section{Relationship between environmental performance and competitive advantage}

Existing literature is not clear as to whether GSCM is economical or not, and if a company will enjoy competitor advantages if it is implemented. Some companies may even be affected negatively as costs increase and business processes are slowed down (Caniëls et al. 2013). A study conducted by Zhu et al. (2013) empirically tested a theoretical model on the different types of pressures that encourage companies to implement GSCM. The results of this test suggested that GSCM practises do not noticeably affect the economic performance of a company, but that the improved environmental and operation performances do create better economic performances in the long term. It was found that green supply chain management enhances economic performance indirectly rather than directly. The study by Fujii, Iwata, Kaneko and Managi (2013) established that environmental performance is related to economic performance in Japanese manufacturing companies. Collaboration between stakeholders and suppliers can assist the realisation of environmental and economic goals.
Relationship between greening the supplier and environmental performance and between greening the supplier and competitive advantage

When choosing their suppliers based on the environmental sustainability, many companies, whilst valuing and viewing ecological aspects as a high priority, do not recognise their own contributions. Research by Large, Kramer and Hartmann (2013) and Walker et al. (2008) identified that suppliers are not the driving force that makes supply chains more sustainable, it is rather a heightened awareness of the need to integrate the environment into the supply chain. The focal companies should create this awareness as the public are holding them responsible for degrading environmental impacts. Companies that do not scrutinise and monitor their suppliers may be at risk (Caniëls et al. 2013). Many companies' environmental corporate images may be damaged by poor environmental performances of suppliers. Companies therefore need to provide suppliers with clear environmental requirements and design specifications to ensure that environmental goals are reached (Li 2011).

Collaboration between suppliers and companies to share logistical data and create universal standards and practices can lead to both parties' corporate sustainability. Suppliers should be invited to early product design meetings to ensure early supplier involvement (ESI) and to incorporate management strategies, for example, just in time (JIT) (Zhu et al. 2013). By sharing this data, all the role players can predict environmental impacts and ways to mitigate these impacts effectively (Kroes 2011). However, companies do need to assist their suppliers in meeting regulations and certification requirements. The negative aspect of enforcing certification is that suppliers may comply only to fulfil the requirements. They may not view the certification as beneficial to them or as a starting block to initiate more green innovation (Caniëls et al. 2013).

Two case studies regarding fresh fruit export supply chains were undertaken by Muller, Vermeulen and Glasbergen (2012). Two business strategies for the export of fresh fruit between Britain and South Africa to achieve sustainable supply chains were investigated. The first strategy had a prescriptive, paternalistic, pushing approach whereby business standards were enforced. This lead to poor communication and misunderstandings that translated into a negative image for the parties involved and in unnecessary costs incurred. The approach of the second strategy was more collaborative and encouraged partnerships and open communication lines. The study concluded that a collaborated, shared-value approach supply chain is more successful than a prescriptive, paternalistic, pushing strategy. This confirms that suppliers should be the first movers in order to outperform their competitors (Zhu, Sarkis \& Lai 2012) because innovation brings about operational, environmental and economic benefits for them.

\section{Motivation for study}

The motivation for the study was that GSCM is still a relatively new research area in South Africa. The publication rate in South Africa has decreased since 1990 (Walz \& 
Eichhammer 2012). According to the available literature, greening the supplier and green innovation has a positive influence on companies' competitive advantage and environmental performance (Tseng et al. 2013). This study explored the relationships between greening the supplier, green innovations (product, process and management) and its influence on environmental performance and competitive advantage in the City of Johannesburg Metropolitan Municipality region. This research has therefore contributed to research on Green Supply Chain Management in a South African context and simultaneously created awareness about environmental aspects for supply chain managers. A similar study to test the relationship between greening the supplier, green innovation, environmental performance and competitive advantage was conducted in Taiwan by Chiou et al. (2011). The study concluded by stating that greening the supplier, through green innovation, results in benefits to the company in terms of environmental performance and competitive advantage. The questionnaire used in this study was adapted from this research.

\section{Research strategy \\ Research method}

The design made use of questionnaire survey data from various manufacturing and retail companies in the City of Johannesburg Metropolitan Municipality region in order to perform confirmatory factor analysis followed by bivariate correlations to determine strength of association between the latent constructs. The purpose was to evaluate the theoretical causal relationships between the various latent constructs within the questionnaire. The hypotheses were derived from the literature review and the study conducted by Chiou et al. (2011). See Table 1 for the hypotheses.

Confirmatory factor analysis was used in this model to evaluate the relationship between the observed and unobserved variables and to assess the internal consistency within each latent construct. The unobserved, or latent constructs, were grouped into (1) Greening the Supplier, (2) Green Innovation (comprised of Green product innovation, Green Process Innovation and Green Managerial Innovation), (3) Environmental Performance and (4) Competitive Advantage. Once the reliability of these observed items in constructing the unobserved constructs was determined, correlations between the different constructs were analysed. The different observed items in the questionnaire were grouped and averaged to form an index for each of the latent constructs. Kendall's tau b correlation coefficient was used to determine the direction and strength of the relationships between the latent constructs. Kendall's tau b is a non-parametric correlation coefficient that makes use of ranking to determine association and is therefore suitable in the scenario where the distances between the indices are not meaningful. IBM SPSS 21.0 (IBM, USA) was used to conduct the analysis.

\section{Sample size and data collection}

Questionnaires were distributed to some manufacturing and retail companies within the City of Johannesburg

\begin{tabular}{|c|c|}
\hline Hypothesis number & Hypothesis \\
\hline $\mathrm{H} 1 \mathrm{a}$ & $\begin{array}{l}\text { Greening the supplier is positively associated with green } \\
\text { product innovation. }\end{array}$ \\
\hline $\mathrm{H} 1 \mathrm{~b}$ & $\begin{array}{l}\text { Greening the supplier is positively associated with green } \\
\text { process innovation. }\end{array}$ \\
\hline $\mathrm{H} 1 \mathrm{c}$ & $\begin{array}{l}\text { Greening the supplier is positively associated with green } \\
\text { managerial innovation. }\end{array}$ \\
\hline $\mathrm{H} 2 \mathrm{a}$ & $\begin{array}{l}\text { Green product innovation is positively associated with } \\
\text { environmental performance. }\end{array}$ \\
\hline $\mathrm{H} 2 \mathrm{~b}$ & $\begin{array}{l}\text { Green process innovation is positively associated with } \\
\text { environmental performance. }\end{array}$ \\
\hline $\mathrm{H} 2 \mathrm{C}$ & $\begin{array}{l}\text { Green managerial innovation is positively associated } \\
\text { with environmental performance. }\end{array}$ \\
\hline H3а & $\begin{array}{l}\text { Green product innovation is positively associated with } \\
\text { competitive advantage. }\end{array}$ \\
\hline $\mathrm{H} 3 \mathrm{~b}$ & $\begin{array}{l}\text { Green process innovation is positively associated with } \\
\text { competitive advantage. }\end{array}$ \\
\hline $\mathrm{H} 3 \mathrm{c}$ & $\begin{array}{l}\text { Green managerial innovation is positively associated } \\
\text { with competitive advantage. }\end{array}$ \\
\hline $\mathrm{H} 4$ & $\begin{array}{l}\text { Environmental performance is positively associated with } \\
\text { competitive advantage. }\end{array}$ \\
\hline H5 & $\begin{array}{l}\text { Greening the supplier is positively associated with } \\
\text { environmental performance. }\end{array}$ \\
\hline H6 & $\begin{array}{l}\text { Greening the supplier is positively associated with } \\
\text { competitive advantage. }\end{array}$ \\
\hline $\mathrm{H7a}$ & $\begin{array}{l}\text { Green product innovation is positively associated with } \\
\text { green process innovation. }\end{array}$ \\
\hline $\mathrm{H} 7 \mathrm{~b}$ & $\begin{array}{l}\text { Green managerial innovation is positively associated } \\
\text { with green process innovation. }\end{array}$ \\
\hline H7c & $\begin{array}{l}\text { Green managerial innovation is positively associated } \\
\text { with green product innovation. }\end{array}$ \\
\hline
\end{tabular}

Source: adapted from a study by Chiou, T., Chan, H.K., Lettice, F. \& Chung, S.H., 2011, 'The influence of greening the supplier and green innovation on environmental performance and competitive advantage in Taiwan', Transportation Research Part E 47, 822-836

Metropolitan Municipality region. Purposeful sampling was used in selecting the companies. This method of sampling is appropriate in scenarios where the sampling frame is not available and a specific group of respondents are targeted. Questionnaires were distributed to lower or middle management and in scenarios where these managers were not available, staff with sufficient knowledge regarding the supply chain and within the same department where substituted as the respondents. The questionnaire and the purpose of the questionnaire were personally explained to the respondent. The respondent completed the questionnaire in the presence of the fieldworker and it was not left at the company to collect at a later stage. The items on the questionnaires were adopted from a study by Chiou et al. (2011).

The sample size for this study equalled 75 observations in total. The responses of 'I don't know' were excluded in deriving the correlation coefficients, but were used in the reliability analysis. The reason behind this exclusion was that, due to the general lack of disclosed information on environmental issues, it was reasonable to assume that the respondents did not have access to, or knowledge of, the requested information.

\section{Reliability analysis}

Reliability analysis measures consistency, repeatability and the precision or lack of distortions of the indicators (Chiou et al. 2011). Cronbach's Alpha was used as a measure of internal consistency. It indicates how reliable the different sub-items or indicator variables within a specific group 
measure the latent structure that they have assigned to them. Values above 0.7 indicate strong internal consistency, values between 0.5 and 0.7 indicate moderate internal consistency and values below 0.5 indicate relatively weak internal consistency. The corrected item-total correlation (ITC) values indicate each item's contribution to the Cronbach's Alpha value of the latent construct.

Values below 0.4 were evaluated and those significantly lower were removed. Two items in the questionnaire showed very low correlations and were removed from the analysis. The remaining items below 0.4 were considered in light of the change of the Cronbach's Alpha value and were removed. These values (C21, C18) were not removed because of the relatively low increase in Cronbach's Alpha. A summary of the reliability analysis between the different latent constructs and the indicator variables was also done and can be found in Table 2.

\section{Results and analysis}

The Kendall's tau b correlation coefficients used to measure the strength of association between the latent constructs are presented in Table 3, together with the respective bootstrapped confidence intervals. The coefficient values ranged from -1 to +1 ; where -1 indicated a strong negative association and +1 a strong positive association. Values close to 0 indicated statistical independence. The confidence intervals accounted for both sample size and standard deviation and could therefore be used to indicate the reliability of the estimates. Confidence intervals with large ranges were indicative of less reliable estimates than confidence intervals with smaller ranges. The table was ranked according to correlation coefficients, where the largest coefficient (strongest association) of constructs was presented first.

\section{Discussion}

The results indicate an overall positive correlation between all the latent constructs measured. However, these correlations do vary in both strength and significance. Green process innovation and environmental performance $(\mathrm{H} 2 \mathrm{~b})$ show the strongest correlation of 0.573 , a value that is generally defined as a moderately strong relationship. These values do not imply causation between the constructs, but there is a definite positive relationship present. A green innovative process minimises resource utilisation, waste, energy use and pollution, thus benefitting the environment.

The relationship between greening the supplier and green product innovation ( $\mathrm{H} 1 \mathrm{a})$ has the second highest correlation significance with a value of 0.549 . If a supplier is invited, by focal companies, to early product design meetings and is supported to explore innovative products, they will become more green and sustainable. The supplier will in turn produce products that are green and innovative.

Competitive advantage is, relative to the other constructs, very strongly associated with green innovation, green product innovation ( $\mathrm{H} 3 \mathrm{~b})$ and managerial innovation (H3c). If companies consider consumer needs and provide them with green innovative products, the companies will be the first movers and will acquire the associated financial gain and competitive advantage. Whilst green innovation is comprised of various different constructs, managerial innovation is comprised of only one and is therefore seen

TABLE 2: Reliability coefficients.

\begin{tabular}{|c|c|c|c|c|c|c|}
\hline Latent construct & Question asked & Indicator variable & Code & $\begin{array}{l}\text { Corrected item- } \\
\text { total correlation }\end{array}$ & $\begin{array}{l}\text { Cronbach's } \\
\text { Alpha if item } \\
\text { deleted }\end{array}$ & $\begin{array}{l}\text { Cronbach's } \\
\text { Alpha }\end{array}$ \\
\hline \multirow[t]{5}{*}{$\begin{array}{l}\text { Greening the } \\
\text { supplier }\end{array}$} & \multirow{5}{*}{$\begin{array}{l}\text { Has your company } \\
\text { ever taken the } \\
\text { following actions } \\
\text { with your suppliers or } \\
\text { subcontractors: }\end{array}$} & $\begin{array}{l}\text { Selected suppliers or subcontractors based on environmental } \\
\text { criteria? }\end{array}$ & B12 & 0.429 & 0.693 & 0.721 \\
\hline & & $\begin{array}{l}\text { Required suppliers or subcontractors to obtain a third-party } \\
\text { certification of Environmental Management Systems (EMS) } \\
\text { such as ISO 14000? }\end{array}$ & B13 & 0.480 & 0.673 & - \\
\hline & & $\begin{array}{l}\text { Provided environmental awareness seminars or training for } \\
\text { your suppliers? }\end{array}$ & B14 & 0.420 & 0.699 & - \\
\hline & & $\begin{array}{l}\text { Provided environmental technical advice to suppliers and } \\
\text { sub-contractors? }\end{array}$ & B15 & 0.590 & 0.626 & - \\
\hline & & $\begin{array}{l}\text { Sent in-house auditors to appraise the environmental } \\
\text { performance of suppliers? }\end{array}$ & B17 & 0.485 & 0.671 & - \\
\hline \multirow{3}{*}{$\begin{array}{l}\text { Green product } \\
\text { innovation }\end{array}$} & \multirow{3}{*}{$\begin{array}{l}\text { Has your company ever } \\
\text { taken the following } \\
\text { actions: }\end{array}$} & Used less non-polluting or toxic materials? & C18 & 0.394 & 0.439 & 0.556 \\
\hline & & $\begin{array}{l}\text { Designed and improved environmentally friendly packaging } \\
\text { for products? }\end{array}$ & C19 & 0.439 & 0.365 & - \\
\hline & & Used-eco labelling? & $\mathrm{C} 21$ & 0.322 & 0.599 & - \\
\hline \multirow[t]{2}{*}{$\begin{array}{l}\text { Green process } \\
\text { innovation }\end{array}$} & \multirow{2}{*}{$\begin{array}{l}\text { Has your company ever } \\
\text { taken the following } \\
\text { actions during the } \\
\text { production process: }\end{array}$} & $\begin{array}{l}\text { Lowered consumption of natural resources (e.g., Water, } \\
\text { electricity, gas or petrol)? }\end{array}$ & D22 & 0.419 & - & 0.581 \\
\hline & & Used cleaner or renewable technologies to make savings? & $\mathrm{D} 23$ & 0.419 & - & - \\
\hline \multirow{3}{*}{$\begin{array}{l}\text { Environmental } \\
\text { performance }\end{array}$} & \multirow{3}{*}{$\begin{array}{l}\text { Has your company } \\
\text { performed better when } \\
\text { compared to your main } \\
\text { competitors in the } \\
\text { following areas: }\end{array}$} & Reduction of hazardous waste, emissions, et cetera? & E25 & 0.657 & 0.788 & 0.824 \\
\hline & & $\begin{array}{l}\text { Consumption of fewer resources such as energy, water, gas } \\
\text { petrol, et cetera? }\end{array}$ & E26 & 0.749 & 0.692 & - \\
\hline & & Compliance to environmental regulations? & E27 & 0.645 & 0.792 & - \\
\hline \multirow[t]{4}{*}{$\begin{array}{l}\text { Competitive } \\
\text { advantage }\end{array}$} & \multirow{4}{*}{$\begin{array}{l}\text { Your company's } \\
\text { competitive advantages } \\
\text { are: }\end{array}$} & $\begin{array}{l}\text { Customer satisfaction in relation to product design and } \\
\text { development? }\end{array}$ & E28 & 0.707 & 0.690 & 0.795 \\
\hline & & Product design and innovation skills? & E29 & 0.624 & 0.736 & - \\
\hline & & Production cost? & E30 & 0.616 & 0.745 & - \\
\hline & & Quality of product and service? & E31 & 0.509 & 0.791 & - \\
\hline
\end{tabular}


TABLE 3: Kendall's tau b coefficients between latent constructs.

\begin{tabular}{|c|c|c|c|}
\hline Construct & Correlation coefficient & $95 \%$ Confidence interval lower & $95 \%$ Confidence interval upper \\
\hline Green process innovation and environmental performance & $0.573 * *$ & 0.339 & 0.801 \\
\hline Greening the supplier and green product innovation & $0.549 * *$ & 0.110 & 0.540 \\
\hline Greening the supplier and green innovation & $0.504^{* *}$ & 0.326 & 0.669 \\
\hline Green managerial innovation and competitive advantage & $0.480 * *$ & 0.177 & 0.712 \\
\hline Green innovation and environmental performance & $0.458 * *$ & 0.235 & 0.642 \\
\hline Green managerial innovation and green process innovation & $0.457^{* *}$ & 0.201 & 0.707 \\
\hline Green innovation and competitive advantage & $0.456^{* *}$ & 0.268 & 0.623 \\
\hline Green product innovation and green process innovation & $0.448 * *$ & 0.196 & 0.670 \\
\hline Green product innovation and green managerial innovation & $0.426^{* *}$ & 0.154 & 0.637 \\
\hline Green managerial innovation and green product innovation & $0.426^{* *}$ & 0.154 & 0.637 \\
\hline Green process innovation and competitive advantage & $0.423^{* *}$ & 0.148 & 0.645 \\
\hline Greening the supplier and green managerial innovation & $0.392^{* *}$ & 0.164 & 0.578 \\
\hline Green managerial innovation and greening the supplier & $0.392^{* *}$ & 0.164 & 0.578 \\
\hline Green product innovation and environmental performance & $0.389 * *$ & 0.132 & 0.607 \\
\hline Greening the supplier and green process innovation & $0.343^{* *}$ & 0.110 & 0.540 \\
\hline Green product innovation and competitive advantage & $0.306^{* *}$ & 0.070 & 0.532 \\
\hline Green managerial innovation and environmental performance & $0.296 *$ & -0.022 & 0.576 \\
\hline Greening the supplier and competitive advantage & 0.208 & -0.430 & 0.421 \\
\hline Environmental Performance and competitive advantage & 0.200 & -0.078 & 0.513 \\
\hline
\end{tabular}

*, Correlation is significant at the 0.05 level (2-tailed).

$*^{*}$, Correlation is significant at the 0.01 level (2-tailed).

as the primary driver for ensuring competitive advantage. This confirms the literature that the competitiveness of a company is dependent on internal environmental leadership and that green management innovation is one of the most important ways to be competitive. Green managerial innovation also correlates strongly with green process and product innovation ( $\mathrm{H} 7 \mathrm{~b}$ and $\mathrm{H} 7 \mathrm{c})$, which further confirms the notion that management can influence the way products are processed.

The constructs, green product innovation and green process innovation (H7a) are further strongly associated with each other, with a value of 0.448 , which means that a new green product complements to the green innovative process. The association between greening the supplier and managerial innovation (H1c), environmental performance (H5) and green process innovation (H3a) is still significant, but has a weaker correlation, where the values range between 0.392 and 0.343 .

Greening the supplier (H6) and environmental performance (H4) do not show a significant correlation with competitive advantage. When considering the strong correlation between managerial innovation and competitive advantage, as opposed to the non-significant correlation between greening the supplier and competitive advantage, it would be reasonable to deduce that competitive advantage is gained more from internal factors like management than external factors such as supplier orientation or behaviour.

The weak association between environmental performance and competitive advantage suggests that the impact of environmental awareness has not yet gained sufficient momentum to contribute substantially to competitive advantage. The literature review further indicates that it is not clear whether environmental performance does affect economic performance. The improved environmental operation and, specifically green innovative products, creates better economic advantages in the long term. Environmental performance does not influence economic performance directly, but improves it indirectly. Even though greening the supplier and competitive advantage do not have a strong correlation, greening the supplier by means of green innovation does have a strong correlation with competitive advantage.

\section{Conclusions and recommendations}

The research found that a green innovative process has a significant effect on environmental performance. Greening the supplier will initiate greener product innovation and green managerial innovation has a significant correlation with competitive advantage. The primary result of the study indicates that all the constructs positively relate to each other, meaning that the greening of suppliers by means of green innovation leads to enhanced environmental performance and competitive advantages. Based on the results of the study the following recommendations are made.

In management decisions, where advancing environmental performance is the primary motivation, the findings from this study recommend greater focus in green process innovation as opposed to the other latent constructs. Similarly, in scenarios where green product innovation is of greater concern, the findings suggest greater focus on greening the supplier as opposed to the other constructs. It is therefore recommended that companies assist in greening their suppliers through green innovation strategies as this will lead to improved environmental performance and competitive advantages for both parties. Focal companies should invest in greening their suppliers by providing them with technical assistance, training and involving them in early 
product designing meetings. Collaboration and information sharing amongst focal companies and suppliers lead to green product innovation.

For a company to achieve a competitive advantage, green managerial innovation is required. Internal leadership can only effect proactive innovation. To ensure a competitive advantage is obtained, management should have the environment as their focus in all activities that the company is involved in. Management must formulate and commit to an environmental vision and strategies. For a company to initiate and implement GSCM and a greener process, management is once again responsible for providing the guidance and environmental leadership.

Companies should not view environmental protection activities and greening their supply chain as detrimental to the company or as something that must be avoided. The reduction of waste, minimising natural resource usage and the prevention of pollution can all contribute to cost savings for a company. Incorporating green issues into the company will enhance their corporate image and provide them with new market opportunities and shares. Companies that develop and initiate green innovation will have the first mover advantage over their competitors.

The study indicates that companies in the City of Johannesburg Metropolitan Municipal region are starting to initiate and adopt GSCM through green process innovation. The study further raises awareness of the benefits that can be derived from considering the environment and initiating a greener supply chain.

The researchers are aware of the fact that, for some of the respondents, the green environmental concepts are new and that they may not comprehend the applicability thereof to their companies. The dependence on one middle manager respondent from a company to evaluate green practises maybe be subjective and biased, as he or she might not have an overall view of the company's entire supply chain. Because of the small number of participants, the study is not conclusive, but more exploratory in nature, and therefore the results cannot be generalised. Further research, to compare similar industries in relation to their environmental performance and competitive advantage, is indicated by interviewing top management of companies.

\section{Acknowledgements Competing interests}

The authors declare that they have no financial or personal relationship(s) that may have inappropriately influenced them in writing this article.

\section{Authors' contributions}

The nature of the contribution made by each of the authors is: U.v.d.B. (University of South Africa) was the project leader, J-P.L. (University of South Africa) performed the statistics and H.v.d.B. (University of Johannesburg) made conceptual contributions.

\section{References}

Caniëls, M.C.J., Gehrsitz, M.H. \& Semeijn, J., 2013, 'Participation of suppliers in greening supply chains: An empirical analysis of German automotive suppliers', Journal of Purchasing and supply management 19(3), 134-143. http://dx.doi. org/10.1016/j. pursup.2013.02.005

Chen, Y.S., Lai, S.B. \& Wen, C.T., 2006, 'The influence of green innovation performance on corporate advantage in Taiwan', Journal of Business Ethics 67, 331-339. http:// dx.doi.org/10.1007/s10551-006-9025-5

Chen, Y., Chang, C. \& Wu, F., 2012, 'Origins of green innovations: The differences between proactive and reactive green innovations', Management Decisions 50(3), 368-398. http://dx.doi.org/10.1108/00251741211216197

Chiou, T., Chan, H.K., Lettice, F. \& Chung, S.H., 2011, 'The influence of greening the supplier and green innovation on environmental performance and competitive advantage in Taiwan', Transportation Research Part E 47, 822-836. http://dx.doi. org/10.1016/j.tre.2011.05.016

Eltayeb, T.K., Zailani, S. \& Ramayah, T., 2011, 'Green supply chain initiatives among certified companies in Malaysia and environmental sustainability: Investigating the outcomes', Resources, Conservation and Recycling 55, 495-506. http://dx.doi. org/10.1016/j.resconrec.2010.09.003

Fujii, H., Iwata, K., Kaneko, S. \& Managi, S., 2013, 'Corporate environmental and economic performance of Japanese manufacturing firms: Empirical study for economic performance of Japanese manufacturing firms: Empirical study for
sustainable development', Business Strategy and the Environment 22, 187-201. sustainable development', Business
http://dx.doi.org/10.1002/bse.1747

Kroes, R., 2011, 'A supply chain green with envy (and cash)', Supplychaindigital, viewed 09 September 2011, from http://www.supplychaindigital.com/procurement/asupply-chain-green-with-envy-and-cash

Kumar, S., Teichman, S. \& Timpernagel, T., 2012, 'A green supply chain is a requirement for profitability', International Journal of Production Research 50, 1278-1296. http://dx.doi.org/10.1080/00207543.2011.571924

Kurapatskie, B. \& Darnall, N., 2013, 'Which corporate sustainability activities are associated with greater financial payoffs?', Business Strategy and Environment 22, 49-61. http://dx.doi.org/10.1002/bse.1735

Large, R.O., Kramer, N. \& Hartmann, R.K., 2013, 'Procurement of logistics services and sustainable development in Europe: Fields of activity and empirical results', Journal of Purchasing and Supply Management 19(3) 122-133. http://dx.doi. org/10.1016/j.pursup.2013.05.002

Large, R.O. \& Thomsen, C.G., 2011, 'Drivers of green supply chain management performance: Evidence from Germany', Journal of Purchasing and Supply Management 17, 176-184. http://dx.doi.org/10.1016/j.pursup.2011.04.006

Lee, K. \& Kim, J., 2011, 'Integrating suppliers into green product innovation development: An empirical case study in the semiconductor industry', Business Strategy and the Environment 20, 527-538. http://dx.doi.org/10.1002/bse.714

$\mathrm{Li}, \mathrm{Y} ., 2011$, 'Research on the performance measurement of green supply chain management in China', Journal of Sustainable Development 4(3), 101-108. http:// dx.doi.org/10.5539/jsd.v4n3p101

Luke, R. \& Heyns, G., 2013, 'Skills shortages and requirements in the logistics industry in South Africa', 9th Annual State of Logistics Survey for South Africa, 76-82. http://dx.doi.org/10.1002/bse.719

Muller, C., Vermeulen, W.J.V. \& Glasbergen, P., 2012, 'Pushing or sharing as valuedriven strategies for societal change in global supply chains: Two case studies in the British-South African fresh fruit supply chain', Business Strategy and the Environment 21, 127-140.

Parbhoo, P., 2013, 'Sustainability and the green economy: Latest research and insights', presentation at Green Supply Chain Morning Seminar on 13 August 2013 in Sandton, Promech.

SAPA, 2009, 'South African firms "not green enough"', viewed 20 September 2011, from www.southafrica.info/news/business/207879.htm

Schiederig, T., Tietze, F. \& Herstatt, C., 2012, 'Green innovation in technology and innovation management: An exploratory literature review', R\&D Management 42(2), 180-192. http://dx.doi.org/10.1111/j.1467-9310.2011.00672.x

Seman, N.A.A., Zakuan, N., Jusoh, A., Arif, M.S.M. \& Saman, M.Z.M., 2012, 'The relationship of green supply chain management and green innovation concept', Procedia-Social and Behavioral Sciences 57, 453-457.

Seuring, S., 2013, 'A review of modelling approaches for sustainable supply chain management', Decision Support Systems 54, 1513-1520. http://dx.doi. org/10.1016/j.dss.2012.05.053

Tseng, M., Huang, F. \& Chiu, S.F.A., 2012, 'Performance drivers of green innovation under complete information', Procedia - Social and Behavioural Sciences 40 234-250.

Tseng, M., Wang, R., Chiu, S.F.A., Geng, Y. \& Lin, Y.H., 2013, 'Improving performance of green innovation practises under uncertainty', Journal of Cleaner Production 40, 71-82. http://dx.doi.org/10.1016/j.jclepro.2011.10.009

Walker, H., Di Sisto, L. \& McBain, D., 2008, 'Drivers and barriers to environmental supply chain management practices: Lessons from the public and private sectors', Journal of Purchasing and Supply Management 14, 69-85. http://dx.doi. sectors', Journal of Purchasing and
org/10.1016/j.pursup.2008.01.007

Walz, R. \& Eichhammer, W., 2012, 'Benchmarking green innovation', Mineral Economics 24, 79-101. http://dx.doi.org/10.1007/s13563-012-0016-y

Zhu, Q., Sarkis, J. \& Lai, K., 2012, 'Green supply chain management innovation diffusion and its relationship to organizational improvement: An ecological modernization perspective', Journal of Engineering and Technology Management 29, 168-185. http://dx.doi.org/10.1016/j.jengtecman.2011.09.012

Zhu, Q., Sarkis, J. \& Lai, K., 2013, 'Institutional-based antecedents and performance outcomes of internal and external green supply chain management practices' Journal of Purchasing and Supply Management 19(2), 106-117. http://dx.doi. org/10.1016/j.pursup.2012.12.001 